\title{
Adoption of Web 2.0 Tools as Learning Instrument in Tanzania Higher Education. Where are WE?
}

\author{
Ashiraf H. Abeid \\ Mzumbe University \\ Mzumbe - Morogoro \\ Tanzania
}

\begin{abstract}
This research paper investigated the awareness, the use and factors hindering the adoption of web 2.0 tools for academic knowledge creation and sharing in higher learning institutions in Tanzania. Structured questionnaires were used to collect data from the targeted respondents (i.e. lecturers and students). Findings from the study revealed that majority of both students and lecturers are very much aware of the different web 2.0 tools, however the academic use of web 2.0 tools is still very limited as opposed to developed nations. This implies that adoption and use of web 2.0 tools still have a long journey before holding its ground in higher learning institutions in Tanzania. Factors hindering the adoption and educational use of web 2.0 tools were established in the study whereby the critical issue identified was the lack of institutional support and strategies to use web 2.0 tools among the stakeholders. It was therefore recommended that institutions formulate policies and strategies that will guide and support the adoption and uses of web 2.0 tools in the higher learning environment because both students and lecturers were very much interested to learn and adopt web 2.0 tools for education use.
\end{abstract}

Keywords: Adoption, Web 2.0 tools, higher education.

\section{INTRODUCTION}

Since the introduction of internet technology there has been many efforts to establish various internet application tools for different purposes. A good example of these applications is Web 2.0 tools. Different researchers and institutions have been so much interested on these applications platforms and they have collected and analyze data and tried to recommend the proper use of these technologies. Higher learning institutions are not in exception; they are increasingly researching on the use of new technology (including Web 2.0) in the teaching and learning process in order to enhance and simplify it. Many studies on the use of Web 2.0 tools in education have been done especially in the developed nations (Europe, America and Australia). The concern of this research was to do a very similar study in developing countries (in particular Tanzania) to see whether it will yield to similar or different results which can be generalized for that purpose. A survey instrument was designed to asses and analyzes the use of web 2.0 tools from the perspectives of the Tanzanian students and lecturers.

\section{LITERATURE REVIEW}

The inception of Web 2.0 in the year 2004 marked the beginning of major changes in the manner and ways people used to interact and communicate over the World Wide Web. Different authors have tried to explain the meaning of the term web 2.0 technology as follows: Web 2.0 is an umbrella term which comprises a number of internet applications tools such a wikis, blogs, audio/video podcasting, really simple syndication, (RSS), and social networking, [2]. Those tools normally allow a two interactive and collaborations among users on the World Wide Web. Another definition provided by [7], Web 2.0 was explained as "a new way to use existing Internet technologies such as XML and JavaScript to enable participation, interaction and collaboration among users, content providers and businesses, rather than just the traditional viewing of static Web pages". The two definitions by the two different scholars above have got some basic common characteristics The key features which can be picked from the definitions above are: Web 2.0 use internet to provides interactive and collaborative platforms among users, Web 2.0 allows users to manipulate and make changes of the data in the web, Web 2.0 provides a participatory platforms in which users can add or edit contents and lastly Web 2.0 provide a user friendly environment. These features differentiated Web 2.0 from the previous version of the web.

The important features of Web 2.0 tools described earlier continuously provide opportunities for the users to improve the process of knowledge exchange as such it allow the accessing, creation, reviewing, editing and dissemination of user generated content, [14]). In the previous version of the Web (i.e. Web 1.0) these features were absent and hence interactions between users were absolutely impossible and information mainly flew from one direction only. The introduction of Web 2.0 tools brought revolutions, It is is no longer a question of one way communication but a two ways of communications among the stakeholders. [14] noted that the innovative nature of Web 2.0 technologies has drastically transformed the manner in which organizations and individuals access, consume and publish information on the web.

There are many applications of Web 2.0 tools, marketing people use it as a marketing tool to promote and communicate 
products and service they offer to their customers. So, due to the innovative nature of Web 2.0 tools, there is a substantial evidence for the adoption of Web 2.0 tools among business organizations, in order to enhance communications of their products and services to their stakeholders. For example, [8], in a global survey of the applications of Web 2.0 technologies, shows that there is a high rate of adoption of Web 2.0 technologies by organizations to enhance and sustain their competitive position. In that study, it was observed that things like marketing and promotions of products and services can now be done using some Web 2.0 tools such as social media. In some instance individuals and organizations use web 2.0 tools for formal/informal communications among each other for sharing some important information related to real life experiences and business information. Much as Web 2.0 tools are applied in various areas they are very useful to support the learning and knowledge sharing process in higher education. Advantages of using Web 2.0 tools for supporting teaching and learning process are very obvious: First most of the tools and features of Web 2.0 tools are easy to use and so they do not require one to be a computer/ information and communication technology, (ICT) expert. Only a moderate knowledge of ICT is sufficient for one to use the different Web 2.0 tools. Other advantages of Web 2.0 tools are highlighted as follows: It can increase student's content production, it increase access to classroom resources at any time, it also increase student's motivation and confidence, it enable and increase students to students support and collaborations, it increase student engagement and stimulate collaborative learning. The most important advantage of Web 2.0 tools is that it encourages two ways interactions among students and lecturers beyond the classroom hours. Adoption and uses of social media and other web 2.0 tools for social interactions is growing among people of different ages [14] but its adoption and use by college students and staffs is still very low [2]). This research investigated why?

Different researchers have done surveys from different parts of the world and came up with different results. For example in Australia a research by [3] on the influence of Web 2.0 tools in tourism industries indicated that more and more companies in the tourism sector use varieties of Web 2.0 tools to market their services such as hotel booking and travelling arrangements. This enabled them to save time, cost and improve their performance and it is more convenient and preferred by their customers.

[4] and [5] researches which investigated the use of Web 2.0 technologies by students to enhance academic collaborations in Australia. In the first case they investigated the use of emerging technologies (including Web 2.0) by students. Contrary to what has been said in technology research literatures (e.g. in [11]) students were found not to be active users of technologies to facilitate knowledge sharing in their studies. Specific to Web 2.0 technology it was observed a low usage of web 2.0 tools to enhance knowledge sharing. Despite the fact that majority of students own modern digital devices such as laptops, Tablets and 3G mobile phones/smart phones yet very few of them use them to use Web 2.0 tools for academic knowledge sharing. It was further revealed that awareness of some of Web 2.0 tools such as podcasts was still very low. In the second study [5] investigated the differences between staff and students use of technology in teaching and learning. The results show that only in some of the technologies e.g. gaming, mobile use and web music categories students were very active where as in other categories of technologies such as Web 2.0 the magnitude of the difference was very low, indicating a moderate use of Web 2.0 tools for knowledge sharing. Nevertheless the level of familiarity of Web 2.0 technology among students and staffs was somewhat there but not very much. In Malaysia, [15] investigated the use of Web 2.0 tools by Malaysian students. Their study came up with very similar results as those found by [4] and [5]. That is low use of Web 2.0 tools by students in higher education for academic knowledge sharing, although, in Malaysia it was found that there was very high awareness about Web 2.0 tools and students possesses higher computer knowledge. [9] did a case study research in Malaysia to determine the impact of multimedia learning technologies and Web 2.0 and the way it can be used to promote active collaboration in learning environment. It was revealed from the study that students were so active and successful in using Web 2.0 tools especially blogs for creating a collaborative learning environment between themselves and their lecturers, furthermore blogs helped them to improve their team working and communications skills. These results contravene those founded by [4] and [15]. However precautions should be taken when comparing those results. This is because the study by [9] was administered to a group 
of second year students taking a subject "multimedia technologies" in which students were coached, guided and helped to create blogs and websites as part of the course assessments structure which could be the reason for active utilization of Web 2.0 tools that was observed.

Other studies exploring the use of Web 2.0 technologies in higher education include [2] who investigated the use of Web 2.0 technology and its implications to higher education sector in the west. Findings of his study showed that some Universities in the UK and USA use some Web 2.0 tools such as wikis, blogs and bookmaking to facilitate the exchange of academic information between students and staffs. There were also some cases in UK Universities where students and staffs were assisted in using some of these tools for knowledge sharing purposes. Students and staffs were very active and use Web 2.0 tools to stimulate the learning process among themselves. Another study was done by [6] investigated students' perceptions on the usefulness of Web 2.0 technologies in learning. This study was conducted to undergraduate students from different disciplines of studies. Despite the fact that the response of most students indicated high awareness on Web 2.0 tools yet their experience of using Web 2.0 tools to enhance knowledge sharing is still lacking among them as most of them confirmed that they have never used web 2.0 tools for academic knowledge sharing. These results also contradict with the results obtained by [2]. Another study by [1], examined the awareness of faculty members on the benefits of using Web 2.0 tools to supplement traditional teaching methods in the United States. The findings revealed that majority of participants indicated very high awareness and appreciated that Web 2.0 tools are useful to provide an active and collaborative learning environment. These results are in line with those found by [6].

[12] and [13] examined the use of social computing to foster lifelong learning and the impact of social media on learning respectively. In the first case their study showed that Universities in UK have took initiatives to implement social computing applications such as wikis, blogs, social networking systems to facilitate knowledge sharing and collaborations among students, lecturers and other administrative staffs. Some cases of lack of interests among users were also discovered as such some web accounts owned by students were found to be inactive. In the second study there were almost similar observations that some social computing technologies have been used but not so widely applied in education. Thus the common findings on the two studies were high awareness on Web 2.0 tools but limited interests on using them for educational purpose. Looking at many technology management literatures awareness and usage of new technologies especially among youths is seen and reported to be high, [11], but the real situation seems to be a different stories. See for example [12] research results which indicate that the number of youths adopted and use social media had increased drastically by the year 2007 and 2008 but when you compare their use for education purposes is still very low. What does this mean then? This means that more specific studies on the use of Web 2.0 in the education sector will help to generate a wider understanding of the real situation on the use of Web 2.0 technologies that could help to improve the current situation as most studies reviewed indicated that the level of Web 2.0 tools applications for academic knowledge sharing is still low.

\subsection{The Research Problem}

Many previous researches investigated the use of web 2.0 technology found that the level of awareness of web 2.0 technology is high, [15] and [9] However the high level of awareness of web 2.0 tools does not match with the extent of their use especially for creation and sharing of academic knowledge, [9]. This indicates that Web 2.0 tools are not utilized to their full potentials to enhance knowledge sharing among students and lecturers in higher education. Furthermore studies to investigate why the use of Web 2.0 tools to enhance knowledge sharing in higher learning institutions are still limited, many studies were done in Europe, America, Australia and Asia while very few such studies has been conducted for developing countries context especially Africa. This study is an attempt to fill this gape.

\subsection{The Research Objectives}

The main objective of this research paper is to investigate the adoption and utilization of Web 2.0 for the learning process by students and faculty members in higher learning institutions in Tanzania.

The specific objectives are: 
a) To examine Web 2.0 tools awareness and skills among students and lecturers.

b) To analyze the extent of adoption and use of Web 2.0 tools for academic purposes.

c) To analyze factors hindering the use of web 2.0 tools by students and lecturers.

\section{RESEARCH METHODOLOGY}

To achieve the objective of the study the following method was used. First of all literature review was done to assess the adoption and use of Web 2.0 technologies especially to facilitate teaching and learning and the overall process of academic knowledge sharing. This provided insights about Web 2.0 tools adoption and use in higher education from different areas. Then a survey was adopted in order to gather empirical evidence about the use of Web 2.0 technologies by students and lecturers in higher learning institutions. The design of the survey instrument (i.e. questionnaires) was developed based on earlier administered instruments in order to ensure the validity of the survey. Together with that also a pilot study was done to few selected students and lecturers and after satisfactory review then the questionnaires were administered to the targeted respondents. The University staffs surveyed in this study are full time employed academic staffs who have been involved in teaching responsibilities in those institutions. Students who participated in the study were distributed from different levels of studies from undergraduate to postgraduate levels and they were also chosen from different disciplines of studies. Three higher learning institutions were involved, two public universities and one private university. A total of 800 questionnaires (i.e. 200 for lecturers and 600 for students) were distributed among the respondents from different profession. Stratified random sampling technique was adopted whereby the population was first categorized into different subgroups and then randomly selected from each subgroup until a targeted number is reached. 107 and 496 valid responses from lecturers and students respectively were collected.

\section{FINDINGS AND DISCUSION.}

\subsection{Awareness of Web 2.0 Tools}

The responses collected from lecturers and students to assess the awareness of different Web 2.0 tools are shown in table 2. It can be noted that majority of lecturers and students are aware of the different web 2.0 tools, except that both are less aware of RSS Feed and Mashups. In addition to that students are also less aware of bookmarking. Overal it is convincing that a large number of both students and lecturers are aware of Web 2.0 tools.
Table 1: Awareness of different Web 2.0 tools:

\begin{tabular}{|l|c|c|c|c|}
\hline \multirow{2}{*}{$\begin{array}{l}\text { Web 2.0 } \\
\text { Tools }\end{array}$} & \multicolumn{2}{|c|}{ Lecturers } & \multicolumn{2}{c|}{ Students } \\
\cline { 2 - 5 } & YES & NO & YES & NO \\
\hline \multirow{3}{*}{ Blogs } & 93 & 14 & 454 & 42 \\
& $(86.9 \%)$ & $(13.1 \%)$ & $(91.5 \%)$ & $(8.5 \%)$ \\
\hline & 56 & 51 & 97 & 399 \\
Flickr & $(52.3 \%)$ & $(47.7 \%)$ & $(19.6 \%)$ & $(80.4 \%)$ \\
\hline & 61 & 46 & 245 & 251 \\
Bookmaking & $(57 \%)$ & $(43 \%)$ & $(49.4 \%)$ & $(50.6 \%$ \\
\hline & 101 & 13 & 402 & 94 \\
SNS & $(94.4 \%)$ & $(12.1 \%)$ & $(81 \%)$ & $(19 \%)$ \\
\hline & 105 & 2 & 409 & 87 \\
Wikis & $(98.1 \%)$ & $(1.9 \%)$ & $(82.5 \%)$ & $(17.5 \%)$ \\
\hline & 48 & 59 & 210 & 286 \\
Mashups & $(44.9 \%)$ & $(55.1 \%)$ & $(42.3 \%)$ & $(57.7 \%)$ \\
\hline & 11 & 96 & 188 & 308 \\
RSS Feed & $(10.3 \%)$ & $(89.7 \%)$ & $(37.9 \%)$ & $(62.1 \%)$ \\
\hline & 87 & 20 & 382 & 114 \\
Podcasting & $(81.3 \%)$ & $(18.7 \%)$ & $(77 \%)$ & $(23 \%)$ \\
\hline & 94 & 13 & 428 & 68 \\
Tagging & $(87.9 \%)$ & $(12.1 \%)$ & $(86.3 \%)$ & $(13.7 \%)$ \\
\hline
\end{tabular}

\subsection{Skills on How to Use Web 2.0 Tools}

Respondents were then asked about their skills on how to use different Web 2.0 tools. Social Networking Sites, SNS, blogs, wikis, podcasting and bookmarking were the leading known web 2.0 tools among lecturers with a mean score values of above 4 . (see table 2 ). These were followed by flickr and tagging which scored an avaerage 3+. RSS feed and mashups have the lowest mean score of $2+$. This indicated that lecturers have high skills in most of web 2.0 tools and minimum skills on how to use RSS feeds and mashups.

Table 2: Lecturers skills on how to use different Web 2.0 tools

\begin{tabular}{|c|c|c|c|c|c|c|}
\hline Tool & 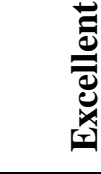 & $\begin{array}{ll}0 & 0 \\
0 & 0 \\
2 & 0 \\
0 & 0 \\
0 & 0\end{array}$ & $\begin{array}{l}0 \\
0 \\
0 \\
\sigma \\
0 \\
0 \\
2\end{array}$ & 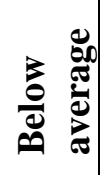 & 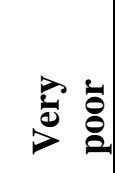 & 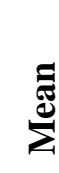 \\
\hline $\mathrm{B} \log \mathrm{s}$ & $\begin{array}{c}45 \\
(42 \%) \\
\end{array}$ & $\begin{array}{c}34 \\
(31 \%) \\
\end{array}$ & $\begin{array}{c}22 \\
(21 \%) \\
\end{array}$ & $\begin{array}{c}6 \\
(5 \%) \\
\end{array}$ & $\begin{array}{c}0 \\
(0 \%) \\
\end{array}$ & 4.1 \\
\hline Flickr & $32(30)$ & $\begin{array}{c}40 \\
(37 \%)\end{array}$ & $\begin{array}{c}11 \\
(10 \%)\end{array}$ & $\begin{array}{c}6 \\
(6 \%)\end{array}$ & $\begin{array}{c}18 \\
(17 \%)\end{array}$ & 3.6 \\
\hline $\begin{array}{l}\text { Bookma } \\
\text { king }\end{array}$ & $\begin{array}{c}59 \\
(52 \%)\end{array}$ & $\begin{array}{c}23 \\
(22 \%)\end{array}$ & $\begin{array}{c}16 \\
(15 \%)\end{array}$ & $\begin{array}{c}0 \\
(0 \%)\end{array}$ & $\begin{array}{c}9 \\
(8 \%)\end{array}$ & 4.1 \\
\hline SNS & $\begin{array}{c}69 \\
(64 \%) \\
\end{array}$ & $\begin{array}{c}22 \\
(21 \%)\end{array}$ & $\begin{array}{c}13 \\
(12 \%)\end{array}$ & $\begin{array}{c}2 \\
(1 \%)\end{array}$ & $\begin{array}{c}1 \\
(0.9 \%) \\
\end{array}$ & 4.5 \\
\hline Wikis & $\begin{array}{c}59 \\
(55 \%) \\
\end{array}$ & $\begin{array}{c}19 \\
(18 \%)\end{array}$ & $\begin{array}{c}21 \\
(19 \%) \\
\end{array}$ & $\begin{array}{c}6 \\
(5 \%) \\
\end{array}$ & $\begin{array}{c}2 \\
(1.9 \%) \\
\end{array}$ & 4.2 \\
\hline Mashups & $\begin{array}{c}21 \\
(19 \%) \\
\end{array}$ & $\begin{array}{c}16 \\
(15 \%)\end{array}$ & $\begin{array}{c}11 \\
(10 \%)\end{array}$ & $\begin{array}{c}39 \\
(36 \%) \\
\end{array}$ & $\begin{array}{c}20 \\
(18 \%)\end{array}$ & 2.8 \\
\hline $\begin{array}{l}\text { RSS } \\
\text { Feed }\end{array}$ & $\begin{array}{c}39 \\
(3 \%)\end{array}$ & $\begin{array}{c}12 \\
(11 \%)\end{array}$ & $\begin{array}{c}18 \\
(16 \%)\end{array}$ & $\begin{array}{c}27 \\
(25 \%)\end{array}$ & $\begin{array}{c}11 \\
(10 \%)\end{array}$ & 3.4 \\
\hline $\begin{array}{l}\text { Podcasti } \\
\text { ng }\end{array}$ & $\begin{array}{c}57 \\
(53 \%) \\
\end{array}$ & $\begin{array}{c}20 \\
(18 \%) \\
\end{array}$ & $\begin{array}{c}16 \\
(15 \%)\end{array}$ & $\begin{array}{c}9 \\
(8 \%) \\
\end{array}$ & $\begin{array}{c}5 \\
(5 \%) \\
\end{array}$ & 4.1 \\
\hline Tagging & $\begin{array}{c}46 \\
(43 \%) \\
\end{array}$ & $\begin{array}{c}24 \\
(22 \%) \\
\end{array}$ & $\begin{array}{c}12 \\
(11 \%)\end{array}$ & $\begin{array}{c}18 \\
(17 \%)\end{array}$ & $\begin{array}{c}7 \\
(6 \%) \\
\end{array}$ & 3.7 \\
\hline
\end{tabular}


Table 3: Students skills on how to use different Web 2.0 tools

\begin{tabular}{|c|c|c|c|c|c|c|}
\hline Tool & 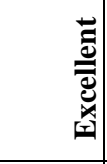 & 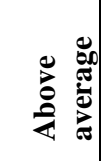 & 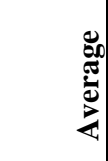 & ف & $\begin{array}{l}\dot{a} \\
\dot{b} \\
\dot{b} \\
\vec{b}\end{array}$ & 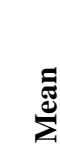 \\
\hline Blogs & $\begin{array}{c}211 \\
(45 \%) \\
\end{array}$ & $\begin{array}{c}106 \\
(21 \%) \\
\end{array}$ & $\begin{array}{c}89 \\
(17 \%) \\
\end{array}$ & $\begin{array}{c}49 \\
(9 \%) \\
\end{array}$ & $\begin{array}{c}41 \\
(8 \%) \\
\end{array}$ & 3.5 \\
\hline Flickr & $\begin{array}{c}53 \\
(11 \%)\end{array}$ & $\begin{array}{c}65 \\
(13 \%) \\
\end{array}$ & $\begin{array}{c}76 \\
(15 \%)\end{array}$ & $\begin{array}{c}168 \\
(34 \%)\end{array}$ & $\begin{array}{c}134 \\
(27 \%)\end{array}$ & 2.5 \\
\hline $\begin{array}{l}\text { Bookm } \\
\text { aking }\end{array}$ & $\begin{array}{c}121 \\
(24 \%)\end{array}$ & $\begin{array}{c}72 \\
(14 \%)\end{array}$ & $\begin{array}{c}45 \\
(9 \%)\end{array}$ & $\begin{array}{c}122 \\
(25 \%)\end{array}$ & $\begin{array}{c}136 \\
(27 \%)\end{array}$ & 2.8 \\
\hline SNS & $\begin{array}{c}286 \\
(58 \%) \\
\end{array}$ & $\begin{array}{c}77 \\
(15 \%)\end{array}$ & $\begin{array}{c}83 \\
(17 \%)\end{array}$ & $\begin{array}{c}27 \\
(5 \%) \\
\end{array}$ & $\begin{array}{c}23 \\
(4 \%) \\
\end{array}$ & 4.2 \\
\hline Wikis & $\begin{array}{c}203 \\
(41 \%) \\
\end{array}$ & $\begin{array}{c}98 \\
(20 \%)\end{array}$ & $\begin{array}{c}83 \\
(17 \%)\end{array}$ & $\begin{array}{c}72 \\
(14 \%) \\
\end{array}$ & $\begin{array}{c}40 \\
(8 \%) \\
\end{array}$ & 3.7 \\
\hline $\begin{array}{l}\text { Mashu } \\
\text { ps }\end{array}$ & $\begin{array}{c}61 \\
(12 \%) \\
\end{array}$ & $\begin{array}{c}63 \\
(13 \%) \\
\end{array}$ & $\begin{array}{c}49 \\
(10 \%) \\
\end{array}$ & $\begin{array}{c}108 \\
(22 \%) \\
\end{array}$ & $\begin{array}{c}215 \\
(43 \%) \\
\end{array}$ & 2.3 \\
\hline $\begin{array}{l}\text { RSS } \\
\text { Feed }\end{array}$ & $\begin{array}{c}119 \\
(24 \%)\end{array}$ & $\begin{array}{c}79 \\
(16 \%) \\
\end{array}$ & $\begin{array}{c}48 \\
(10 \%) \\
\end{array}$ & $\begin{array}{c}114 \\
(23 \%)\end{array}$ & $\begin{array}{c}136 \\
(27 \%) \\
\end{array}$ & 2.8 \\
\hline $\begin{array}{l}\text { Podcast } \\
\text { ing }\end{array}$ & $\begin{array}{c}177 \\
(36 \%)\end{array}$ & $\begin{array}{c}80 \\
(16 \%)\end{array}$ & $\begin{array}{c}132 \\
(26 \%)\end{array}$ & $\begin{array}{c}84 \\
(17 \%)\end{array}$ & $\begin{array}{c}23 \\
(5 \%)\end{array}$ & 3.6 \\
\hline $\begin{array}{l}\text { Taggni } \\
\mathrm{g}\end{array}$ & $\begin{array}{c}35 \\
(22 \%)\end{array}$ & $\begin{array}{c}62 \\
(12 \%)\end{array}$ & $\begin{array}{c}29(5.8 \\
\%)\end{array}$ & $\begin{array}{c}33 \\
(7 \%) \\
\end{array}$ & $\begin{array}{c}14 \\
(3 \%) \\
\end{array}$ & 1.1 \\
\hline
\end{tabular}

From the student's side SNS, blogs, wikis and podcasting were the leading known web 2.0 tools with a mean score above 3 . They are followed by bookmarking, tagging and RSS feed with a mean score of about 2. Mashups is the last one with a mean score of 1.1. From these findings we can simply conclude that majority of lecturers and students at least have some skills on how to use different web 2.0 tools. Only few tools RSS feed and mashups (for lecturers) and mashups and bookmarking (for students) indicating minimal skills among respondents. Although respondents (both students and lecturers) indicate such minimal skills on those few tools but it is important to reiterate that most of Web 2.0 tools are very simple to learn and use, it is only a question of being ready and support.

\subsection{Uses of Web 2.0 Tools}

Web 2.0 tools can be used for different purposes, in the education setting as well as other non academic purposes. Respondents of this study were asked to indicate the different ways where they use web 2.0 tools and the results were as follows:

About the use of web 2.0 tools to search and download academic materials majority of both lecturers (96\%) and students (80\%) agreed that they always or often use Web 2.0 tools for that purpose, none of the lecturers and few students rarely or never use web 2.0 tools for that purpose.
Table 4: Lecturers' uses of different Web 2.0 tools

\begin{tabular}{|c|c|c|c|c|c|}
\hline $\begin{array}{l}\text { Possible use of } \\
\text { web } 2.0 \text { tools }\end{array}$ & $\frac{\pi}{2}$ & ฮี & 冚 & : & \\
\hline $\begin{array}{l}\text { Search and } \\
\text { download } \\
\text { academic } \\
\text { materials } \\
\end{array}$ & $\begin{array}{c}90 \\
(84 \%) \\
\end{array}$ & $\begin{array}{c}12 \\
(11 \%)\end{array}$ & $\begin{array}{c}5 \\
(5 \%) \\
\end{array}$ & $\begin{array}{c}0 \\
(0 \%) \\
\end{array}$ & $\begin{array}{c}0 \\
(0 \%) \\
\end{array}$ \\
\hline $\begin{array}{l}\text { Facilitate online } \\
\text { academic } \\
\text { discussions }\end{array}$ & $\begin{array}{c}14 \\
(13 \%)\end{array}$ & $\begin{array}{c}21 \\
(20 \%)\end{array}$ & $\begin{array}{c}17 \\
(16 \%)\end{array}$ & $\begin{array}{c}18 \\
(17 \%)\end{array}$ & $\begin{array}{c}37 \\
(35 \%)\end{array}$ \\
\hline Research & $\begin{array}{c}97 \\
(91 \%)\end{array}$ & $\begin{array}{c}10 \\
(9 \%)\end{array}$ & $\begin{array}{c}0 \\
(0 \%)\end{array}$ & $\begin{array}{c}0 \\
(0 \%) \\
\end{array}$ & $\begin{array}{c}0 \\
(0 \%)\end{array}$ \\
\hline $\begin{array}{l}\text { Update on } \\
\text { related topic } \\
\text { of interest }\end{array}$ & $\begin{array}{c}84 \\
(79 \%) \\
\end{array}$ & $\begin{array}{c}9 \\
(8 \%) \\
\end{array}$ & $\begin{array}{c}14 \\
(13 \%)\end{array}$ & $\begin{array}{c}0 \\
(0 \%) \\
\end{array}$ & $\begin{array}{c}0 \\
(0 \%) \\
\end{array}$ \\
\hline $\begin{array}{l}\text { Online } \\
\text { submissions of } \\
\text { assignment/pap } \\
\text { ers }\end{array}$ & $\begin{array}{c}54 \\
(51 \%) \\
\end{array}$ & $\begin{array}{c}18 \\
(17 \%)\end{array}$ & $\begin{array}{c}9 \\
(8 \%) \\
\end{array}$ & $\begin{array}{c}16 \\
(15 \%)\end{array}$ & $\begin{array}{c}10 \\
(9 \%) \\
\end{array}$ \\
\hline $\begin{array}{l}\text { Contents } \\
\text { creations and } \\
\text { sharing with } \\
\text { others }\end{array}$ & $\begin{array}{c}34 \\
(32 \%)\end{array}$ & $\begin{array}{c}16 \\
(15 \%)\end{array}$ & $\begin{array}{c}22 \\
(21 \%)\end{array}$ & $\begin{array}{c}12 \\
(11 \%)\end{array}$ & $\begin{array}{c}23 \\
(22 \%)\end{array}$ \\
\hline $\begin{array}{l}\text { Official/Profess } \\
\text { ional } \\
\text { communication }\end{array}$ & $\begin{array}{c}48 \\
(45 \%)\end{array}$ & $\begin{array}{c}16 \\
(15 \%)\end{array}$ & $\begin{array}{c}21 \\
(19 \%)\end{array}$ & $\begin{array}{c}22 \\
(21 \%)\end{array}$ & $\begin{array}{c}1 \\
(1 \%)\end{array}$ \\
\hline $\begin{array}{l}\text { Social } \\
\text { communication }\end{array}$ & $\begin{array}{c}82 \\
(76 \%)\end{array}$ & $\begin{array}{c}11 \\
(10 \%)\end{array}$ & $\begin{array}{c}8 \\
(8 \%)\end{array}$ & $\begin{array}{c}4 \\
(4 \%)\end{array}$ & $\begin{array}{c}2 \\
(2 \%)\end{array}$ \\
\hline
\end{tabular}

Table 5: Student's uses of different Web 2.0 tools.

\begin{tabular}{|c|c|c|c|c|c|}
\hline $\begin{array}{l}\text { Possible use of } \\
\text { web } 2.0 \text { tools }\end{array}$ & $\hat{e}_{\bar{z}}^{n}$ & 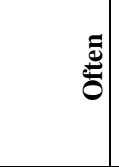 & 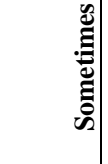 & 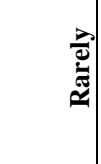 & : \\
\hline $\begin{array}{l}\text { Search and } \\
\text { download } \\
\text { academic } \\
\text { materials }\end{array}$ & $\begin{array}{c}298 \\
(60 \%)\end{array}$ & $\begin{array}{c}103 \\
(21 \%)\end{array}$ & $\begin{array}{c}55 \\
(11 \%)\end{array}$ & $\begin{array}{c}31 \\
(6 \%)\end{array}$ & $\begin{array}{c}9 \\
(2 \%)\end{array}$ \\
\hline $\begin{array}{l}\text { Facilitate online } \\
\text { academic } \\
\text { discussions }\end{array}$ & $\begin{array}{c}193 \\
(39 \%)\end{array}$ & $\begin{array}{c}106 \\
(22 \%) \\
\end{array}$ & $\begin{array}{c}39 \\
(8 \%) \\
\end{array}$ & $\begin{array}{c}77 \\
(15 \%) \\
\end{array}$ & $\begin{array}{c}81 \\
(16 \%)\end{array}$ \\
\hline Research & $\begin{array}{c}254 \\
(51 \%)\end{array}$ & $\begin{array}{c}142 \\
(29 \%)\end{array}$ & $\begin{array}{c}79 \\
(16 \%)\end{array}$ & $\begin{array}{c}13 \\
(3 \%) \\
\end{array}$ & $\begin{array}{c}08 \\
(2 \%) \\
\end{array}$ \\
\hline $\begin{array}{l}\text { Update on } \\
\text { related topic } \\
\text { of interest }\end{array}$ & $\begin{array}{c}135 \\
(27 \%)\end{array}$ & $\begin{array}{c}88 \\
(18 \%) \\
\end{array}$ & $\begin{array}{c}92 \\
(19 \%) \\
\end{array}$ & $\begin{array}{c}123 \\
(25 \%)\end{array}$ & $\begin{array}{c}58 \\
(12 \%) \\
\end{array}$ \\
\hline $\begin{array}{l}\text { Online } \\
\text { submissions of } \\
\text { assignment/pap } \\
\text { ers }\end{array}$ & $\begin{array}{c}42 \\
(9 \%)\end{array}$ & $\begin{array}{c}30 \\
(6 \%) \\
\end{array}$ & $\begin{array}{c}29 \\
(6 \%) \\
\end{array}$ & $\begin{array}{c}107 \\
(22 \%) \\
\end{array}$ & $\begin{array}{c}288 \\
(58 \%) \\
\end{array}$ \\
\hline $\begin{array}{l}\text { Contents } \\
\text { creations and } \\
\text { sharing with } \\
\text { others }\end{array}$ & $\begin{array}{c}81 \\
(16 \%)\end{array}$ & $\begin{array}{c}42 \\
(9 \%)\end{array}$ & $\begin{array}{c}99 \\
(20 \%)\end{array}$ & $\begin{array}{l}135 \\
(27 \%)\end{array}$ & $\begin{array}{c}139 \\
(28 \%)\end{array}$ \\
\hline $\begin{array}{l}\text { Official/Profess } \\
\text { ional } \\
\text { communication }\end{array}$ & $\begin{array}{c}88 \\
(18 \%)\end{array}$ & $\begin{array}{c}100 \\
(20 \%)\end{array}$ & $\begin{array}{c}79 \\
(16 \%)\end{array}$ & $\begin{array}{c}98 \\
(20 \%)\end{array}$ & $\begin{array}{c}131 \\
(20 \%)\end{array}$ \\
\hline
\end{tabular}




\begin{tabular}{|l|c|c|c|c|c|} 
Social & 348 & 16 & 56 & 30 & 46 \\
communication & $(70 \%)$ & $(3 \%)$ & $(11 \%)$ & $(6 \%)$ & $(9 \%)$ \\
\hline
\end{tabular}

About the use of web 2.0 tools to facilitate online academic discussion; it appears that lecturers and students have conflicting opinions. While about $33 \%$ of lecturers always or often use web 2.0 tools to facilitate online academic discussion, about $61 \%$ of students agreed that they always or often use web 2.0 tools for that purposes. Majority of lecturers $(53 \%)$ and minority of students $(16 \%)$ never or rarely used web 2.0 tools for online academic discussion. The reason for such conflicting opinions could be that few lecturers have already adopted and engaging their students on web 2.0 tools to facilitate academic knowledge sharing while others are less interested about it. Regarding the use of web 2.0 tools for research purposes; both lecturers and students had the same opinions, where $(99 \%)$ of lecturers and $(80 \%)$ of students agree that they always and often use web 2.0 tools for research purposes only few of them have denied it.

About the use of web 2.0 tools to update on related academic topics of interest, here also the opinions from the students and lecturers were the same though only a simple majority of students (45\%) and majority of lecturers $(87 \%)$ agreed that they always and often used web 2.0 tools to update themselves on various academic topics of interests while $38 \%$ of students and none of lecturers said that they rarely or never used it for that purpose.

About the use of web 2.0 tools for online submission of assignments/papers here there were different opinions. While $68 \%$ of lectures agreed that they use web 2.0 tools for online assignment/papers submission only very few students about $15 \%$ use web 2.0 tools for that purpose. Majority of the students $(80 \%)$ have never or rarely used web 2.0 tools for online submission of assignments/papers. The reason for such difference could be that so far there are only very few lecturers who engaged their students in web 2.0 tools use.

About the use of web 2.0 tools for academic knowledge creation and sharing a simple majority of the lectures (45\%) and minority of students $(25 \%)$ use it for that purpose while minority of the lecturers (33\%) and majority of the students (55\%) have rarely or never used web 2.0 tools for academic contents creation and sharing. Regarding the use of web 2.0 tools for making official academic communications it appears that majority of the lecturer $(60 \%)$ and few students $(38 \%)$ use it for official academic communications while (22\%) of lecturers and $(40 \%)$ of students rarely or never use web 2.0 tools for that purpose. Lastly is the use of web 2.0 tools for social communications (non academic uses) majority of lecturers $(86 \%)$ and students $(73 \%)$ do agree that they used web 2.0 tools for non academic uses while minority of lectures $(6 \%)$ and students (15\%) rarely or never used it for that purpose. From the analysed data above the conclusion which can be drawn for both students and lecturers is that the education use of web 2.0 tools is somehow there but still limited. Although most online activities by students and lecturers to some extent involve learning but they are done in an informal way.

\subsection{Level of Adoption}

Regarding the adoption level of web 2.0 tools for educational purpose both lecturers (66.6\%) and students (61.1\%) confirmed that web 2.0 tools are still at the early stage of adoption. This was also confirmed from findings from previous studies observed in literature review, thus the use of web 2.0 tools will have to overcome a number of factors in order to take its way as it is in higher education sector of the developed nations.

Table 6: Adoption of web 2.0 tools: (Lecturers and students)

\begin{tabular}{|l|l|l|}
\hline Level & Lecturers & Students \\
\hline Early stage of adoption & $71(66.3 \%)$ & $303(61.1 \%)$ \\
\hline Marginal stage level of adoption & $22(20.6 \%)$ & $102(20.6 \%)$ \\
\hline Advanced stage of adoption & $5(4.6 \%)$ & $10(2 \%)$ \\
\hline No comments & $9(8.4 \%)$ & $81(16.4 \%)$ \\
\hline
\end{tabular}

However practical experience shows that the adoption and use of web 2.0 tools to facilitate academic learning and knowledge creation and sharing for both lecturers and students is gaining momentum. The only problem is that there is still an informal adoption and use of web 2.0 tools for academic activities. The use only depends on the efforts of the individual lecturers/students. The use of web 2.0 tools for social (non academic purpose) is observed to be high nevertheless its use for academic purposes is still encouraging. That is to say there is lack of institutional policies, strategies and support on the use of web 2.0 tools to facilitate academic activities.

\subsection{Barriers of using web 2.0 tools}

The importance of using web 2.0 tools to facilitate and enhance teaching and learning process are very obvious, that is why they have attracted the attention of different stakeholders arround the world. But in most developing countries particularly Tanzania the level of adoption is still very low as discovered in this research. The interest of this research was also to analyse the barriers of of using web 2.0 tools and several areas were asesed. That is internet connectivity, the ownership of electronics devices, other factors such as skills,organizational support, social gape, confidence and copy rights and legal issues.

\subsubsection{Internet Connectivity}

Table 7: Internet connectivity

\begin{tabular}{|l|c|c|c|c|}
\hline & \multicolumn{2}{|l|}{ Lecturers } & \multicolumn{2}{l|}{ Students } \\
\hline & YES & NO & YES & NO \\
\hline In & 99 & 8 & $436(87$. & 60 \\
Campus & $(92.3 \%)$ & $(7.5 \%)$ & $9 \%)$ & $(12.1 \%)$ \\
\hline
\end{tabular}




\begin{tabular}{|l|c|c|c|c|} 
Off & 21 & 86 & 124 & 372 \\
Campus & $(19.6 \%)$ & $(80.4 \%)$ & $(25 \%)$ & $(75 \%)$ \\
\hline
\end{tabular}

With regard to internet connectivity this was observed not to be a big problem to all categories of respondents as $92.3 \%$ of lecturers and $87.9 \%$ of students agreed that they have internet connections within the campus. However the problem to both students and lecturers was the absence of internet connectivity when they are outside the university campus. Although this may not sound to be a very big problem but it is important to give it the weight as it deserves given the fact that due to the increase in the number of students enrolled in higher learning institutions in the recent years it is no longer possible to accommodate all the students in campus and thus internet connection outside the campus become crucial.

\subsubsection{Ownership of electronics devices}

Table 9: Ownership of electronic devices

\begin{tabular}{|l|l|l|}
\hline Device & Lecturers & Students \\
\hline Personal laptops & $100(93.5 \%)$ & $388(78.2 \%)$ \\
\hline Desktop computers & $56(52.3 \%)$ & $36(7.3 \%)$ \\
\hline $\begin{array}{l}\text { Tablets (Ipad, samsung } \\
\text { tab etc) }\end{array}$ & $34((31.8 \%)$ & $71(14.3 \%)$ \\
\hline Digitl Cameras & $69(64.5 \%)$ & $92(18.5 \%)$ \\
\hline $\begin{array}{l}\text { Smart phones/phones } \\
\text { with 3G/4G and video } \\
\text { capabilities }\end{array}$ & $88(82.2 \%)$ & $401(80.8 \%)$ \\
\hline
\end{tabular}

With regard to the issue of ownership of electronic devices analysis of the results shows that majority of lecturers $(93.5 \%)$ and students $(78.2 \%)$ own personal laptops, more than $80 \%$ of both lecturers and students own smart phones/phones with $3 \mathrm{G} / 4 \mathrm{G}$ and audio/video capabilities. Also a good number of lecturers own digital cameras and desktop computers while for students only a small number own digital camera. It was also found that very few students and lecturers own tablets. The ownership of electronic devices can be a barrier to use web 2.0 tools, but from the statistics obtained from this study (see table 7) above it appears that majority of the respondents own the basic electronic devices which can enable them to access the internet and use various web 2.0 tools, however it should not be completely ignored that there are some few students (the minority) who doesn't own the basic electronic devices which will enable them to be part of this process. So to a small extent ownership of electronic devices is a barrier to use web 2.0 tools because no one should be left behind if we formalize the use of Web 2.0 tools in the teaching and learning process. The institutions are supposed to provide support to this category of respondents especially students.

\subsection{Other barriers of using web 2.0 tools}

Other barriers of using web 2.0 tools were assessed by using a number of self reflection statements. Respondents were required to indicate if they agree with the stated barriers and the results were as follows:

Regarding the skills on how to use web 2.0 tools and general ICT skills it was founded that both students and lecturers have a good command of web 2.0 tools and ICT skills (see table $9 / 10$ ). Therefore it can be concluded that web 2.0 tools and ICT skills was not a big obstacle as far as web 2.0 tools adoption and application is concerned.

With regard to institutional support both respondents strongly agree that there was a lack of institutional support especially the technical and administrative support to the use of web 2.0 tools.

Table 9: Barriers of using web 2.0 tools (LECTURERS)

\begin{tabular}{|c|c|c|c|c|c|}
\hline $\begin{array}{l}\text { Barriers } \\
\text { of web } 2.0 \\
\text { tools } \\
\text { adoption. }\end{array}$ & 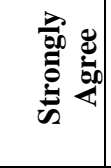 & 离 & $\begin{array}{l}\bar{J} \\
\text { Z } \\
\text { Z } \\
\text { Z }\end{array}$ & 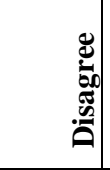 & 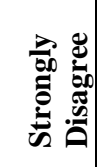 \\
\hline $\begin{array}{l}\text { Insufficient } \\
\text { skills } \\
\text { (IT+Web } \\
2.0 \text { tools) }\end{array}$ & $\begin{array}{c}1 \\
(1 \%)\end{array}$ & $\begin{array}{c}0 \\
(0 \%)\end{array}$ & $\begin{array}{c}3 \\
(2 \%)\end{array}$ & $\begin{array}{c}22 \\
(21 \%)\end{array}$ & $\begin{array}{c}81 \\
(75 \%)\end{array}$ \\
\hline $\begin{array}{l}\text { Lack of } \\
\text { Institutional } \\
\text { support }\end{array}$ & $\begin{array}{c}76 \\
(71 \%)\end{array}$ & $\begin{array}{c}19 \\
(18 \%)\end{array}$ & $\begin{array}{c}8 \\
(7 \%)\end{array}$ & $\begin{array}{c}4 \\
(3 \%)\end{array}$ & $\begin{array}{c}0 \\
(0 \%)\end{array}$ \\
\hline $\begin{array}{l}\text { Lack of } \\
\text { confidence }\end{array}$ & $\begin{array}{c}65 \\
(61 \%)\end{array}$ & $\begin{array}{c}34 \\
(32 \%)\end{array}$ & $\begin{array}{c}5 \\
(5 \%)\end{array}$ & $\begin{array}{c}3 \\
(3 \%)\end{array}$ & $\begin{array}{c}0 \\
(0 \%)\end{array}$ \\
\hline $\begin{array}{l}\text { Social gap } \\
\text { between } \\
\text { students and } \\
\text { lecturers }\end{array}$ & $\begin{array}{c}76 \\
(71 \%) \\
\end{array}$ & $\begin{array}{c}18 \\
(17 \%)\end{array}$ & $\begin{array}{c}10 \\
(9 \%)\end{array}$ & $\begin{array}{c}0 \\
(0 \%)\end{array}$ & $\begin{array}{c}3 \\
(3 \%)\end{array}$ \\
\hline $\begin{array}{l}\text { Copyright } \\
\text { and } \\
\text { legal issues }\end{array}$ & $\begin{array}{c}24 \\
(22 \%)\end{array}$ & $\begin{array}{c}28 \\
(26 \%)\end{array}$ & $\begin{array}{c}50 \\
(47 \%)\end{array}$ & $\begin{array}{c}5 \\
(5 \%)\end{array}$ & $\begin{array}{c}0 \\
(0 \%)\end{array}$ \\
\hline
\end{tabular}

Regarding the lack of confidence there were conflicting opinions where by lecturers didn't agree that lack of confidence is a barrier whereas majority of students consider it to be a barrier so to some extent this was a barrier in using web 2.0 tools. Respondents were then asked about the social gap between students and lecturers and the results indicate that the majority of both lecturers and students strongly agree that there is a social gap between staff and lecturers and hence this was a barrier of adopting and using web 2.0 tools (see table 9/10). Some respondents especially students goes further into explaining this by saying "when it comes to communication or interactions among ourselves, we are okay i.e. we are very free to use any form of communication including different web 2.0 tools however when it comes to communication with lecturers you have to be careful because some lecturers are very selective." Some lectures are not flexible to use varieties of technologies including web 2.0 tools for academic interactions purposes.

The other barrier assessed was copyrights and legal issues. A simple majority of lecturers and the majority of students agree that it is a barrier. Though respondents identify this as a barrier however there are a big number of electronic academic 
materials which are allowed to be used and they can be shared freely for educational purpose thus it may be inappropriate to consider this to be a big obstacle.

Table 10: Barriers of using web 2.0 tools (STUDENTS)

\begin{tabular}{|c|c|c|c|c|c|}
\hline $\begin{array}{l}\text { Barriers } \\
\text { of web } 2.0 \\
\text { tools } \\
\text { adoption. }\end{array}$ & 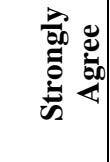 & 党 & 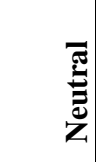 & 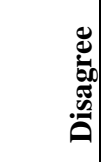 & 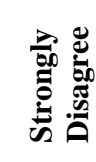 \\
\hline $\begin{array}{l}\text { Insufficient } \\
\text { skills } \\
\text { (IT+Web } \\
2.0 \text { tools) }\end{array}$ & $\begin{array}{c}199 \\
(40 \%) \\
\end{array}$ & $\begin{array}{c}58 \\
(12 \%) \\
\end{array}$ & $\begin{array}{c}63 \\
(13 \%) \\
\end{array}$ & $\begin{array}{c}44 \\
(9 \%) \\
\end{array}$ & $\begin{array}{c}132 \\
(27 \%)\end{array}$ \\
\hline $\begin{array}{l}\text { Lack of } \\
\text { Institutional } \\
\text { support }\end{array}$ & $\begin{array}{c}276 \\
(56 \%)\end{array}$ & $\begin{array}{c}108 \\
(22 \%)\end{array}$ & $\begin{array}{c}83 \\
(17 \%)\end{array}$ & $\begin{array}{c}11 \\
(2 \%)\end{array}$ & $\begin{array}{c}18 \\
(3 \%)\end{array}$ \\
\hline $\begin{array}{l}\text { Lack of } \\
\text { confidence }\end{array}$ & $\begin{array}{c}59 \\
(11 \%)\end{array}$ & $\begin{array}{c}24 \\
(5 \%)\end{array}$ & $\begin{array}{c}0 \\
(0 \%)\end{array}$ & $\begin{array}{c}342 \\
(69 \%)\end{array}$ & $\begin{array}{c}71 \\
(14 \%)\end{array}$ \\
\hline $\begin{array}{l}\text { Social gap } \\
\text { between } \\
\text { students and } \\
\text { lecturers }\end{array}$ & $\begin{array}{c}300 \\
(60 \%)\end{array}$ & $\begin{array}{c}97 \\
(20 \%)\end{array}$ & $\begin{array}{c}22 \\
(4 \%)\end{array}$ & $\begin{array}{c}42 \\
(8 \%)\end{array}$ & $\begin{array}{c}35 \\
(7 \%)\end{array}$ \\
\hline $\begin{array}{l}\text { Copyright } \\
\text { and } \\
\text { legal issues }\end{array}$ & $\begin{array}{c}33 \\
(7 \%)\end{array}$ & $\begin{array}{c}18 \\
(4 \%)\end{array}$ & $\begin{array}{c}70 \\
(14 \%)\end{array}$ & $\begin{array}{c}211 \\
(43 \%)\end{array}$ & $\begin{array}{c}164 \\
(33 \%)\end{array}$ \\
\hline
\end{tabular}

It is clearly understood that the introduction of any new thing like technology, to any institution will have to overcome some opponents and it is therefore the responsibility of organizational leaders to manage the changes appropriately in order to overcome this problem. It should clearly be insisted the need to innovate the teaching and learning process in order to make it much more attractive and participatory especially during this time which is said to be the digital era.

\section{SUMMARY AND \\ RECOMMENDATIONS:}

The results presented in the previous section above highlighted a number of important issues related to adoption and use of web 2.0 tools. The questions that were asked in the questionnaires sought to understand the awareness and skills on various web 2.0 tools analyze the extent of adoption of web 2.0 tools and analyze the factors hindering the adoption of web 2.0 tools among students and lecturers.

In general students and lecturers skills and awareness on web 2.0 tools is very positive as observed that majority of respondents have high skills and are aware of the different web 2.0 tools. However some respondents indicated unfamiliarity with some web 2.0 tools such as mashups and podcasting. This may be due to lack of interest in the use of those particular tools for learning purposes.

About adoption and the use of web 2.0 tools it was established that adoption level of web 2.0 tools is still at the early and informal stage however majority of students and lecturers in one way or the other have used web 2.0 tools for learning and other social purposes. Some findings from previous researches especially in the developed nation's shows that students and lecturers have already enter into the marginal and advanced level of adoption. By making a direct comparison with the results of this study it is very clear that Tanzanian students and lecturers are lagging behind. However personal experiences during data collection process shows that both students and lecturers are very much interested to adopt and use web 2.0 tools for learning purposes. It is therefore upon the institutions especially those which are interested to increase the use of technology in the teaching/learning process. They should focus their attention, efforts and investments to support this area. Particular attentions should be paid to insist the advantages of using web 2.0 tools and other technologies in the general learning process. In case skills and technical support is needed it should be provided.

Regarding the barriers of using web 2.0 tools it is important to note that most respondents i.e. lecturers and students acknowledged the benefits of web 2.0 tools application in education but there are some barriers identified which inhibit them from actively using web 2.0 tools. The major ones were lack of institutional support, the social gap between students and lecturers, resistance to change and lack of innovation. The minor ones were lack of confidence copyrights/legal issues and insufficient skills. Looking at the barriers above one can definitely say that lack of institutional support and strategies to formalize web 2.0 tools application in the teaching and learning process is the major issue of concern, therefore it is recommended that efforts should be increased to facilitate the adoption and use of web 2.0 tools for improving and enhancing the teaching and learning processes.

\section{CONCLUSIONS}

The results of this research have provided more insights about students and lecturers adoption and use of web 2.0 tools to facilitate the teaching and learning process. The general finding is that both students and lecturers at least are aware and have some knowledge about web 2.0 tools though the adoption and use of web 2.0 tools in education is still very low and informal. The general recommendation is that there should be establishment of institutional strategies to support the adoption and use of web 2.0 tools for the teaching and learning process. Both stakeholders i.e. students, lecturers and the institutions should play a shared responsibility in order to ensure teaching and learning process by using web 2.0 tools yield the intended outcomes.

\section{REFERENCES:}

[1] Ajjan H. \& Hartshorne, R., (2008), Investigating Faculty Decision to adopt web 2.0 technologies: Theory and Empirical tests, [online], Internet \& Higher education journal, Volume 11 (2) pp. 71 80 available from http://webpages.csus.edu/sac43949/PDFs/Faculty\% 20Decisons\%20Web\%202.0.pdf 
International Journal of Computer Applications Technology and Research

Volume 5- Issue 5, 266 - 274, 2016, ISSN:- 2319-8656

[2] Anderson, P. (2007), What is web 2.0? Ideas Technology and Implications for Education, [online], JISC, Technology and Standards Watch, available from www.jisc.ac.uk

[3] Elton, N.M., (2013), Web 2.0 and its Influence in the tourism sector, European Scientific Journal volume 9 Issue 20 available online from http://eujournal.org/files/journals/1/articles/1565/pu blic/1565-4687-1-PB.pdf

[4] Kennedy, G. et al, (2007), The net generations are not big users of web 2.0 technologies. Preliminary findings, [online], Proceedings Ascilite Singapore 2007, pp. 517 - 526, available from http://www.ascilite.org.au/conferences/singapore07/ procs/kennedy.pdf

[5] Kennedy, G. et al., (2008), immigrants and Natives: Investigating the differences between staffs and students use of technologies in learning, [online], Proceedings of Ascillite, Melbourne, 2008, pp. 484 $-492$

[6] Kumar, S. (2008) Undergraduate perceptions of the usefulness of web 2.0 in higher education, survey development, [online], University of Florida, USA, Proceedings of the European conference on eLearning, pp. 306 - 314, available from http://webtools4teachers.yolasite.com

[7] Lawton, G. (2007) Web 2.0 and Security Challenges, Technology News, Published by IEEE Computer Society

[8] McKinsey \& Company, (2007), How business Organizations are using Web 2.0: A McKinsey Global Survey, [online], available from www.mckinseyquartely.com

[9] Neo,T.K, Neo, M \& Kwok, W.J.J., (2009), Engaging students in a multimedia corporations learning environments: A Malaysian experience, [online], Proceedings of the Ascillite, Auckland, 2009, p.p. 674 - 683, available from http://www.ascillite.org.au/conferences/auckland09/ procs/neo.pdf

[10] Platt, M., 2009, Web 2.0 in the Enterprises, [online], Architecture Journal, Volume 12, issue, 2 pp. 1-5, available from http://msdn.microsoft.com/enus/library/bb735306.aspx

[11] Prensky, M. (2001). Digital Natives, Digital Immigrants, The Horizon, MCB University Press, Vol. 9(5) available online from http://www.marcprensky.com/writing/Prensk $\% 20-$

\%20Digital\%20Natives, \%20Digital\%20Immigrants \%20-\%20Part1.pdf

[12] Redecker, C., Ala-Mutka, K \& Punie, Y., (2010), The Impact of social media on learning in Europe, [online], JRC-EC, Institute for Prospective Technological studies, available from http://ftp.jrc.ec/EURdoc/JRC56958.pdf,

[13] Redecker, C.,Ala-Mutka, K \&Punie, Y., (2008), Learning 2.0: The use of social computing to enhance lifelong learning, [online] Institute for Prospective Technological studies, available from http://is.jrc.ec.eurpa.eu/pages/EADTUpaperFINAL. pdf.pdf

[14] Romero, C. L., Alarcon-del-Amo, M. and Constantinides, E. (2014). Determinants of Use of Social Media Tools in Retailing Sector. Journal of Theoretical and Applied Electronic Commerce Research, Volume 9, Issue 1, 44-55

[15] Zakaria, M. H., Watson, J. \& Edwards, S., (2008), Investigating the use of Web 2.0 technology in Malaysia, [online], Multicultural Education \&Technology Journal, 4(1), pp. 17-29, available from, www.emeraldinsight.com/1750-497X.htm 